\title{
KEBIJAKAN APLIKATIF TINDAK PIDANA PERDAGANGAN ORANG
}

\author{
Nanda Ivan Natsir \\ Fakultas Hukum, Universitas Mataram \\ Jl. Majapahit 62, Mataram \\ Indonesia \\ Email: nandaivanntasir@gmail.com
}

\begin{abstract}
Abstrak
Tujuan penelitian ini adalah untuk mengetahui dan menganalisis bentuk penanggulangan tindak pidana perdagangan orang dan kendala-kendala yang dihadapai di Kepolisian Daerah Nusa Tenggara Barat. Metode penelitian yang digunakan adalah penelitian hukum empiris, lokasi penelitian di Kepolisian Daerah Nusa Tenggara Barat. Bentukbentuk tindak pidana perdagangan orang berdasarkan yaitu: Proses perekrutan eksploitasi seksual (prostitusi), perdagangan anak sebagai pekerja, perdagangan anak melalui adopsi (pengangkatan anak), perekrutan melalui pernikahan dan pengantin pesanan. Kendalakendala Kepolisian Daerah Nusa Tenggara Barat, dalam penanggulangan tindak pidana perdagangan orang yaitu kendala dalam aspek struktur hukum (penegak hukum), sarana atau fasilitas pendukung, faktor masyarakat dan faktor kebudayaan.
\end{abstract}

\section{Kata Kunci : Penegakan Hukum; Perdagangan orang}

\section{A. PENDAHULUAN}

Peningkatan jumlah perdagangan orang di beberapa wilayah negara Asean terutama Indonesia sebagai negara yang memiliki penduduk terbesar ke-empat dunia dipicu oleh perkembangan teknologi sebagai basis operasional organized crime, hal tersebut juga mendorong Pemerintah Indonesia untuk memproteksi melalui pengaturan hukum yang lebih spesifik dengan dikeluarkannya Undang-Undang Nomor 21 Tahun 2007 tentang Pemberantasan Tindak Pidana Perdagangan Orang.

Korban Perdagangan orang adalah terutama pada anak dan perempuan, hal ini berkaitan dengan sifat dasar perempuan dan anak yang memiliki ciri khusus yang dapat dimanfaatkan oleh pelaku sehingga mempermudah cara dan metode kerja pelaku yang terorganisir secara profesional.

Upaya optimalisasi penegakan hukum dalam fungsinya yang berciri kausatif membutuhkan peran dari berbagai elemen, guna mencegah peningkatan korban yang lebih besar, sehingga penting diketahui bentuk-bentuk praktek (modus operandi) perdagangan orang (human trafficking) yang berkembang dan kendala-kendalam penegak hukum sehingga masyarakat dapat membaca melalui pola-pola yang dibangun secara dinamis oleh pelaku (organized crime) dan Pemerintah dapat merumuskan kebijakan yang tepat.

Penelitian ini bertujuan untuk mengetahui bentuk penanggulangan tindak pidana perdagangan orang (human trafficking) oleh Kepolisian Daerah Nusa Tenggara Barat dan untuk mengetahui apa saja kendala- kendala yang dihadapai oleh Kepolisian Daerah Nusa Tenggara Barat dalam penanggulangan tindak pidana perdagangan orang (human trafficking).

\section{B. METODE PENELITIAN}

Penelitian ini menggunakan pendekatan empiris, yaitu pendekatan yang membaca pemaknaan hukum atau pelaksanaan hukum dengan terlebih dahulu membaca dan menganalisa literatur tentang fungsi dan tugas pokok Kepolisian, dan peraturan perundangundangan yang terkait dengan pokok bahasan tersebut. Lokasi penelitian ini adalah di 
Kepolisian Daerah Nusa Tenggara Barat. Dalam pengumpulan data menggunakan tehnik wawancara dan studi dokumen. Analisis menggunakan analisis deskripstif dan analisis Sistematis.

\section{PEMBAHASAN}

\section{Bentuk-Bentuk Tindak Pidana Perdagan- gan OrangBerdasarkan Undang-Undang Nomor 21 Tahun 2007}

Undang-Undang Nomor 21 Tahun 2007 tentang Pemberantasan Tindak Pidana Perdagangan Orang merupakan kristalisasi dari berbagai kesepakatan internasional yang telah disesuaikan dengan endapan nilai-nilai moral masyarakat Indonesia dalam simbol Pancasila. Dalam kaitannya itu, dalam pembahasan bentuk praktik perdagangan orang di Indonesia akan diuraikan berdasarkan Undang-undang Nomor 21 Tahun 2007.

Sesuai pasal 1 ayat (1) memberikan pengertian perdagangan orang sebagai berikut:

"Perdagangan Orang adalah tindakan perekrutan,pengangkutan, penampungan, pengiriman, pemindahan, ataupenerimaan seseorang dengan ancaman kekerasan,penggunaan kekerasan, penculikan, penyekapan, pemalsuan,penipuan, penyalahgunaan kekuasaan atau posisi rentan,penjeratan utang atau memberi bayaran atau manfaat,sehingga memperoleh persetujuan dari orang yang memegangkendali atas orang lain tersebut, baik yang dilakukan di dalamnegara maupun antar negara, untuk tujuan eksploitasi atau mengakibatkan orang tereksploitasi."

Mencermati pengertian perdagangan orang sebagaimana yang telah dipaporkan diatas, setidaknya harus mencakup 3 (tiga) unsur pokok sehingga suatu perbuata $\mathrm{n}$ dapat dikategorikan sebagai perdagangan manusia yaitu :proses, cara, dan tujuan. Untuk lebih jelasnya dapat disimak tabel dibawah ini :
Tabel 1. Alternatif Proses, Cara dan Tujuan Perdagangan Manusia

\begin{tabular}{|c|c|c|}
\hline Proses & Cara & Tujuan \\
\hline 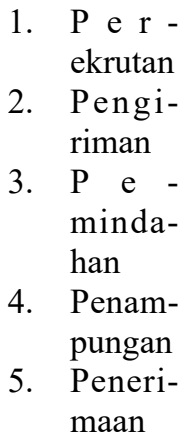 & $\begin{array}{ll}\text { 1. } & \text { Ancaman } \\
\text { 2. } & \text { Pemaksaan } \\
\text { 3. } & \text { Penculikan } \\
\text { 4. Penipuan } \\
\text { 5. Kecurangan } \\
\text { 6. Kebohon- } \\
\text { gan } \\
\text { 7. Penyalah- } \\
\text { g u n a a n } \\
\text { Kekuasaan }\end{array}$ & $\begin{array}{l}\text { 1. Prostitusi } \\
\text { 2. Pornografi } \\
\text { 3. Kekerasan/ } \\
\text { Eksploitasi } \\
\text { 4. Kerja Paksa } \\
\text { 5. Perbudakan/ } \\
\text { Praktek Seru- } \\
\text { pa }\end{array}$ \\
\hline
\end{tabular}

Ketiga unsur pokok tersebut di otas bersifat saling terkait, apabila salah satu faktor dari ketiga kategori tersebut terpenu hi, maka terjadilah perdagangan manusia. Artinya, persetujuan dari korban tidak lagi relevan apabila salah satu cara yang tercanturn diatas digunakan. Untuk kasus perdagangan anak, tidak berlaku syarat persetujuan, sebab banyak kasus perdagangan yang menimpa anak masuk dalam kategori pemaksaan dengan tanpa persetujuon.

Definisi mengenai perdagangan orang mengalami perkembangan sampai ditetapkannya Protocol to Prevent, Suppress and Punish Trafficking in Persons Especially Women and Children Suplementing the United Nation Convention Against Transnational Organized Crime tahun 2000.

Perdagangan orang dalam protokol adalah: "rekrutmen, transportasi, pemindahan, penyembunyian atau penerimaan seseorang, dengan ancaman atau penggunaan kekerasan atau bentuk-bentuk tekanan lain, penculikan, pemalsuan, penipuan atau pencurangan, atau penyalahgunaan kekuasaan atau posisi rentan, ataupun penerimaan/pemberian bayaran, atau manfaat sehingga memperoleh persetujuan dari orang yang memegang kendali atas orang tersebut untuk dieksploitasi, yang secara minimal termasuk ekspolitasi lewat prostitusi atau bentuk-bentuk eksploitasi seksual.

Dari ketentuan pasal 1 ayat (1) diatas beberapa bentuk umum dari perdagangan orang, bentuk itu kemudian dirumuskan sebagai suatu tindak pidana sebagaimana 
yang tertera dalam Pasal 1 ayat (2) yaitu: "Tindak Pidana Perdagangan Orang adalah setiap tindakan atau serangkaian tindakan yang memenuhi unsur-unsurtindak pidana yang ditentukan dalam Undang-Undang ini."

Ketentuan tindak pidana tersebut berangkat dari konsep dasar bahwa perbuatan tersebut dalam pasal 1 ayat (1) adalah bentuk pelanggaran hak asasi manusia berdasarkan hukum tertinggi UUD NRI Tahun 1945 juga nilai dasar Pancasila (groundnorm) pertimbangan beberapa hal ini kemudian yang tercantum dalam konsideran Undang-Undang Nomor 21 Tahun 2007. Penegasan konsideran pembentukan Undang-Undang Nomor 21 Tahun 2007 adalah dasar-dasar penentuan bentuk-bentuk praktik perdagangan orang di Indonesia.

Bentuk-bentuk perdagangan orang ditinjau dari Undang-Undang Nomor 21 Tahun 2007 telah disebutkan dalam pasal 1 ayat (1) yang diperkuat didalam pasal 1 ayat (2) sebagai bentuk tindak pidana. Dari pengertian perdagangan orang yang tercantum dalam pasal 1 ayat (1), maka bentuk-bentuk tindak pidana perdagangan orang dapat dirumuskan sebagai berikut:

\section{a. Bentuk Perekrutan Eksploitasi Seksual (Prostitusi)}

Pasal 1 Undang-Undang Nomor 21 Tahun 2007 memberikan definisi Perekrutan adalah tindakan yang meliputi mengajak, mengumpulkan, membawa, atau memisahkan seseorang dari keluarga atau komunitasnya. Dari pengertian ini, dalam perekrutan dilakukan berbagai cara untuk mengajak korban dan mempengaruhi korban. Dalam banyak kasus, perempuan dan anak-anak dijanjikan bekerja sebagai buruh migran, pembantu rumah tangga, pekerja restoran, penjaga toko, atau pekerjaan-pekerjaan tanpa keahlian tetapi kemudian dipaksa bekerja pada industri seks saat mereka tiba di daerah tujuan. Dalam kasus lain, beberapa perempuan tahu bahwa mereka akan memasuki industri seks tetapi mereka ditipu dengan kondisi-kondisi kerja dan mereka dikekang di bawah paksaan dan tidak diperbolehkan menolak bekerja.

Ketentuan mengenai larangan perdagangan orang khususnya untuk memberantas segala bentuk perdagangan wanita dan eksploitasi pelacuran telah ditegaskan dalam Pasal 6 Convention on the Elimination of All Forms of Discrimination Against Woman ( CEDAW ), sebagaimana telah diratifikasi dengan Undang-Undang Nomor 7 Tahun 1984 tentang pengesahan Konvensi mengenai Penghapusan Segala Bentuk Diskriminasi Terhadap Perempuan.

\section{b. Perdagangan Anak Sebagai Pekerja}

Perkembangan ilmu pengetahuan yang menghasilkan berbagai bentuk teknologi, baik teknologi industri, informasi dan teknologi lain membawa peningkatan kebutuhan dalam berbagai aspek kehidupan, hal ini pula medorong peningkatan kebutuhan tenaga kerja, sehingga dalam berbagai kebutuhan pekerja, untuk menekan biaya produksi memunculkan pemikiran korporasi dalam mencari tenaga kerja yang murah, maka anak seringkali menjadi korban eksploitasi.

Cara-cara yang digunakan dalam eksploitasi anak cenderung merugikan anak, sebagaimana pengertian yang diberikan Undang-undang Nomor 35 Tahun 2014 tentang Perubahan Atas Undang-Undang Nomor 23 Tahun 2002 Tentang Perlindungan Anak pada pasal 1 ayat 16 Bahwa kekerasan adalah setiap perbuatan terhadap Anak yang berakibat timbulnya kesengsaraan ataupenderitaan secara fisik, psikis, seksual, dan/atau penelantaran, termasuk ancaman untukmelakukan perbuatan, pemaksaan, atau perampasan kemerdekaan secara melawan hukum.

Undang-Undang Nomor 23 Tahun 2002 dan Undang-Undang Nomor ro Tahun Y.l $\leq$ tentang Perubahan Atas UndangUndang Nomor rr Tahun 2002 tentang Perlindungan Anak mempertegas bentuk perdagangan anak sebagai bagian penting sekaligus memberikan perlindungan, tercantum pasal sebagai berikut: 
Pasal 83

Setiap orang yang memperdagangkan, menjual, atau menculik anak untuk diri sendiri atau untuk dijual, dipidana dengan pidana penjara paling lama 15 (lima belas) tahun dan paling singkat 3 (tiga)tahun dan denda paling banyak Rp 300.000.000,00 (tiga ratus juta rupiah) dan paling sedikit Rp 60.000.000,00 (enam puluh juta rupiah)

Pasal 88

Setiap orang yang mengeksploitasi ekonomi atau seksual anak dengan maksud untuk menguntungkan diri sendiri atau orang lain, dipidana dengan pidana penjara paling lama 10 (sepuluh) tahun dan/atau denda paling banyak Rp 200.000.000,00 (dua ratus juta rupiah).

Berdasarkan beberapa hal tersebut diatas perdagangan anak dapat diartikan sebagai segala bentuk tindakan dan percobaan tindakan yang melibatkan perekrutan, transportasi baik di dalam maupun antar negara, pembelian, penjualan, pengiriman, dan penerimaan anak dengan menggunakan tipu daya, kekerasan, atau dengan pelibatan hutang untuk tujuan pemaksaan pekerjaan domestik, pelayanan seksual, perbudakan, buruh ijon, atau segala kondisi perbudakan lain, baik anak tersebut mendapatkan bayaran atau tidak, di dalam sebuah komunitas yang berbeda dengan komunitas di mana anak tersebut tinggal ketika penipuan, kekerasan, atau pelibatan hutang tersebut pertama kali terjadi.

Pengertian pekerjaan terburuk untuk anak menurut Undang - Undang Nomor 1 Tahun 2000 tentang Pengesahan Konvensi ILO Nomor 182 mengenai Pelarangan dan Tindakan Segera Penghapusan Bentuk Bentuk Pekerjaan Terburuk untuk Anak di Indonesia secara umum meliputi anak anak yang dieksploitasi secara fisik maupun ekonomi yang antara lain dalam bentuk berikut: ${ }^{1}$

1) Anak - anak yang dilacurkan

2) Anak - anak yang di pertambangan

3) Anak-anakyang bekerja sebagai penyelam mutiara

4) Anak-anakyangbekerjadisektorkonstruksi

5) Anak - anak yang bekerja di jermal

6) Anak-anakyangbekerjasebagaipemulung sampah

7) Anak-anakyang dilibatkan dalamproduksi dan kegiatan yang menggunakan bahan bahan peledak.

8) Anak - anak yang bekerja di jalan.

9) Anak-anakyangbekerja sebagaipembantu rumah tangga

10)Anak - anak yang bekerja di Industri rumah tangga

11) Anak - anak yang bekerja di perkebunan

12)Anak-anakyang bekerja padapenebangan, pengolahan dan pengangkutan kayu

13) Anak - anak yang bekerja pada industri danjeniskegiatanyangmenggunakanbahan kimia yang berbahaya.

Pemerintah menetapkan prioritas penghapusan untuk fase lima tahun pertama hanyapada lima jenis pekerjaan terburuk untuk anak, yaitu anak - anak yang terlibat dalam penjualan, produksi, dan pengedar narkotik (sale, production and trafficking drugs), perdagangan anak (trafficking of children), pelacuran anak (children of protistution), anak-anak yang bekerja sebagai nelayan di lepas pantai (child labour in offshore fishing), pertambangan (mining), dan anak - anak yang bekerja di industri sepatu (footwear). ${ }^{2}$

Percepatan fase sebagaimana prioritas pemerintah diatas dapat terlaksana dengan kerjasama berbagai elemen, salah satu bentuk perlindungan hak anak oleh pemerintah adalah dengan penegakkan hukum dan

Keputusan Presiden tentang Rencana Aksi Nasional ( RAN ) Penghapusan Bentuk -Bentuk Pekerjaan Terburuk untuk Anak, Keppres RI No. 59 Tahun 2002, Lampiran Bab I.

${ }^{2}$ International Labour Organization, Bunga - Bunga di Atas Padas: Fenomena Pekerja Rumah Tangga Anak di Indonesia, Jakarta : ILO - APEC, 2004, hal. 150 
pengawasan yang ketat, selain itu juga upaya preventif dalam jangka panjang baik oleh pemerintah juga seluruh masyarakat. Hal ini penting dilakukan mengingat perkembangan organized crime dalam perekrutan anak memiliki bentuk yang bervariatif.

\section{c. Perdagangan Anak Melalui Adopsi ( Pen- gangkatan Anak )}

Pengaturan tentang pengangkatan anak di Indonesia mulai diatur di dalam Surat Edaran Mahkamah Agung Nomor 2 Tahun 1973 dan disempurnakan dengan SEMA RI Nomor 6Tahun 1983. Isinya selain menetapkan pengangkatan yang langsung dilakukan antara orangtua kandung dengan orang tua angkat, juga tentang pengangkatan anak yang dapat dilakukanoleh WNI yang tidak terikat perkawinan yang sah/ belum menikah dan juga mengatur tatacara mengangkat anak, bahwa:

"Untuk mengangkat anak harus terlebih dahulu mengajukan permohonan pengesahan/ pengangkatan kepada Pengadilan Negeri tempat anak yang akan diangkat itu berada. Bentukpermohonan itu bisa secara lisan ataupun tertulis, dan diajukan ke Panitera Pengadilan Negeritersebut. Permohonan diajukan dan ditandatangani oleh pemohon sendiri atau kuasanya,dengan dibubuhi material secukupnya dan dialamatkan kepada Ketua Pengadilan Negeri yangdaerah hukumnya meliputi tempat tinggal / domisili anak yang akan diangkat".

Prosedur pengangkatan anak memang dilakukan secara ketat untuk melindungi hak-hak anak yang diangkat dan mencegah berbagai pelanggaran dan kejahatan sepertiperdagangan anak. Ketidaktahuan prosedur ini menimbulkan persepsi dimasyarakat bahwamengadopsi anak itu mudah, sehingga sering kali masyarakat bertindak di luar hukum, makadapat terjadi tindak pidana perdagangan anak.

\section{d. Perekrutan melalui Pernikahan dan Pen-}

\section{gantin Pesanan}

Biasanya, praktik perbudakan berkedok pernikahan dan pengantin pesanan dilakukanoleh pria warga negara asing dengan wanita warga negara Indonesia. Salah satu modusoperandi perdagangan orang yang lain adalah pengantin pesanan (mail border bride) yang merupakan pernikahan paksa dimana pernikahannya diatur orang tua. Perkawinan pesanan inimenjadi perdagangan orang apabila terjadi eksploitasi baik secara seksual maupun ekonomimelalui penipuan, penyesengsaraan, penahanan dokumen, sehingga tidak dapat melepaskandiri dari eksploitasi, serta ditutupnya akses informasi dan komunikasi dengan keluarga.

Ada dua bentuk perdagangan melalui perkawinan, yaitu pertama, perkawinandigunakan sebagai jalan penipuan untuk mengambil perempuan tersebut dan membawa kewilayah lain yang sangat asing, namun sesampai di wilayah tujuan perempuan tersebutdimasukkan dalam prostitusi. Kedua, adalah perkawinan untuk memasukkan perempuankedalam rumah tangga untuk mengerjakan pekerjaan - pekerjaan domestik yang sangateksploitatif bentuknya.

Pernikahan dini salah satu pemicu terjadinya tindak pidana perdagangan orang. Hal ini disampaikan oleh Linda Amalia Sari, S.IP, Menteri Negara Pemberdayaan Perempuan dan Perlindungan Anak. $^{3}$ Pola pikir permisif budaya pernikahan dini atau kawin usia muda di beberapa daerahmerupakan salah satu "peluang" yang dimanfaatkan oleh para pelaku tindak pidana perdagangan orang, karena perempuanperempuan yang melakukan perkawinan usia muda, yang secara psikologis dan ekonomis mempunyai tingkat kerentaran yang sangat tinggi untuk melakukan perceraian. Dan di sini-lah letak permasalahannya, yaitu dimana perempuan-perempuan yang sudah menjanda tersebut banyak menjadi korban tindak

\footnotetext{
${ }^{3}$ Gugus Tugas Nasional Pencegahan dan Penanganan Tindak Pidana Perdagangan Orang Pemerintah, website resmi, Indonesia http://www.gugustugastrafficking.org/ index.php/index.php?option $=$ com content\&view $=$ category\&layout $=$ blog\&id=113\&Itemid $=53$
} 
pidana perdagangan orang. "Kepolosan" dan "ketidakpahaman" akan bahaya yang muncul sebagai akibat "bentuk-bentuk terselubung" yang sering mengatasnamakan "bekerja di luar negeri, dengan upah yang jauh lebih tinggi" merupakan faktor pencetus diawalinya perdagangan orang.

Menurut Linda Amalia Sari, ${ }^{4}$

"Kuasa relasi yang tidak seimbang antara peremuan dan laki-laki sebagai akibat dari budaya patriarki yang kurang menguntungkan perempuan, juga memberikan andil yang cukup besar bagi perkembangan tindak kejahatan perdagangan orang

\section{Kendala-Kendala Yang Dihadapi Kepoli- sian Daerah Nusa Tenggara Barat Dalam Penanggulangan Tindak Pidana Perda- gangan Orang (Human Trafficking)}

Berdasarkan hasil penelitian pada Direktorat Reserse Kriminal Kepolisian Daerah Nusa Tenggara Barat, kendala dalam penanggulangan tindak pidana perdagangan orang (human trafficking) adalah meliputi kendala dalam aspek struktur hukum (penegak hukum), sarana atau fasilitas pendukung, faktor masyarakat dan faktor kebudayaan. Lebih lanjut diuraikan dalam sub pokok bahasan berikut.

\section{a. Struktur Hukum (Penegak Hukum)}

Human trafficking, merupakan kejahatan yang tergolong ke dalam crime against humanity dan sulit untuk diungkap. Selain, para pelaku adalah orangorang yang memiliki keahlian, jaringan, serta akses ke berbagai bidang seperti penegak hukum, elit politik, serta aparat keamanan para korban adalah orang- orang yang tidak tahu hukum serta memiliki kepentingan-kepentingan ekonomis, sehingga mudah diperalat/dieksploitasi. Untuk dapat melakukan proses peradilan terhadap kasus-kasus yang berkaitan dengan human trafficking, para penegak hukum tidak dapat bekerja sendiri, sesuai tugas dan fungsinya. Para penegak hukum

${ }^{4}$ Ibid. sangat memerlukan bantuan dari berbagai pihak, seperti laporan dari masyarakat sebagai informasi untuk mengungkap kasus tersebut. Berkaitan dengan itu, Kasubdit IV Ditreskrimum Polda NTB, AKBP Ni Made Pujewati, SIK., MM. memaparkan:5

"Menghadapi perdagangan orang memang memiliki kesulitan tersenidir, $\mathrm{ka}$ rena modus operandi pelaku sulit diketahui, terutama modus untuk bekerja, polisi juga kesulotan kalau tidak ada kerjasama masyarakat, minimal ada laporan terkait agen-agen pencari kerja dari masyarakat, kami sulit bertindak kalau nanti masyarakat enggan menginformasikan."

Berdasarkan tantangan tersebut, maka dalam proses penyidikan, aparat kepolisian harus memiliki kemampuan khusus dalam menangani kasus-kasus human trafficking. Kemampuan khusus ini diperlukan mengingat para pelaku (trafficker) bukanlah orang yang bodoh. Mereka pada umumnya telah mempersiapkan segala upaya, bila terjadi kemungkinan yang melibatkan dirinya secara hukum. "Kelebihan" yang dimiliki para pelaku ini menambah sulitnya pengungkapan kasus-kasus human trafficking oleh aparat kepolisian.

Selain itu, berdasarkan hasil penelitian faktor penegak hukum diakui sebagai faktor yang paling krusial dalam penegakkan hukum, Kasubdit IV Ditreskrimum Polda NTB, AKBP Ni Made Pujewati, SIK., MM. memaparkan: ${ }^{6}$

"Harus kita akui bahwa faktor penegak hukum dalam hal ini kepolisian juga merupaka faktor yang menghambat tujuan kita bersama, masih banyak oknum Polisi yang berpikir instan merupakan kepribadian yang membahayakan keseluru-

${ }^{5}$ Hasil wawancara dengan Kasubdit IV Ditreskrimum Polda NTB, AKBP Ni Made Pujewati, SIK., MM, Polda NT, Tanggal 15 Oktober 2018.

${ }^{6}$ Hasil wawancara dengan Kasubdit IV Ditreskrimum Polda NTB, AKBP Ni Made Pujewati, SIK., MM, Polda NT, Tanggal 15 Oktober 2018.

64 Nanda Ivan Natsir | Kebijakan Aplikatif Tindak Pidana.... 
han instansi, kita semua khawatir dengan keadaan seperti itu, selain itu juga harus diakui kualitas beberapa anggota Kepolisian masih harus perlu ditingkatkan agar mampu menegakkan hukum yang sebaikbaiknya seperti tujuan undang-undang”.

Menurut Soerjono Soekanto, ${ }^{7}$ mentalitas atau kepribadian petugas penegak hukum memainkan peranan penting, kalau peraturan sudah baik, tetapi kualitas petugas kurang baik, ada masalah. Oleh karena itu, salah satu kunci keberhasilan dalam penegakan hukum adalah mentalitas atau kepribadian penegak hukum. Dengan demikian selain sosialisasi atau penyuluhan pada masyarakat terkait kesadaran hukum masyarakat. Penguatan mentalitas personil Kepolisian sangat penting dalam mengoptimalkan tujuan perlindungan hutan.

Dalam penelitian yang sama juga didapat suatu fakta bahwa penegakan hukum oleh aparat terkait menghadapi kendala karena:

1) pandangan institusi peradilan yang memandang perdagangan manusia bukan sebagai suatumasalahhukum. Haliniterkait dengan pemahaman dari aparat penegak hukum terhadap instrumen hukum terkait;

2) tidak aktifnya aparat penegak hukum dan militer dalam mengawasi dan memonitor pelaku perdagangan manusia khususnya yang terorganisasi.

Secara teknis-yuridis, keharusan untuk memperoleh bukti awal yang cukup, dalam menangani kasus-kasus kriminal, menjadi kendala tersendiri bagi aparat kepolisian. Terlebih lagi bila tidak adanya saksi yang mau bersaksi dalam mengungkap adanya human trafficking. Keengganan para saksi untuk menjadi saksi dalam kasus-kasus demikian ini disebabkan karena beberapa hal, berdasar uraian hasil penelitian yaitu sebagai berikut:

1) keengganan karena proses peradilan yang berbelit-belitdanmembutuhkanwaktuyang lama;

\footnotetext{
${ }^{7}$ Soerjono Soekanto. (2004). Faktor-Faktor Yang Mempengaruhi Penegeakan Hukum Cet.Ke-5. Jakarta: Raja Grafindo Persada, hlm. 45
}

2) tidak adanya jaminan keselamatan bagi saksi, dari segala bentuk ancaman;

3) kurangnya perhatian dari aparat terhadap saksi, sehingga saksi menjadi takut atau enggan untuk berurusan dengan aparat penegak hukum

4) alasan waktu dan biaya, merupakan kendala tersendiribagisaksiuntukberurusandengan aparat penegak hukum.

Beberapa hal tersebut menjadi kesulitan yang dialami pada tahap penyelidikan dan penyidikan, memiliki dampak yang sangat luas kepada proses hukum selanjutnya, mengingat pada tahap inilah proses peradilan pidana dimulai.

Upaya dalam menghadapi tantangan struktur hukum dilihat dari reformasi Polri ditegaskan dalam Undang-Undang Nomor 2 Tahun 2002 tentang Kepolisian Negara Republik Indonesia. Berangkat dari semangat perubahan tersebut, maka Polri berusaha membangun pemahaman empirik tentang aspek fungsi kepolisian universal dan pemahaman sosiologis yang terkait dengan sejarah perjuangan dan budaya bangsa Indonesia. Lewat reformasi pula Polri berupaya menggugah semua pihak untuk ikut berperan serta di dalam upaya mewujudkan Polri yang mampu menjawab tantangan profesi masa depan sesuai tuntutan reformasi.

Berkaitan dengan beberapa hal tersebut, berdasarkan hasil penelitian dikatakan bahwa: ${ }^{8}$

Penguatan peranan personil Kepolisian lebih khusus personil Polda NTB dilakukan oleh internal organisasi Kepolisian, penguatan peranan melingkup mentalitas, pengetahuan dan penguasaan personil Polda NTB terhadap materi atau substansi hukum tugas dan fungsi serta terkait batas-batas kewenangan.

Secara operasional, Polri berusaha melakukan perubahan struktural, instrumental dan kultural. Dengan cara itu

${ }^{8}$ Hasil wawancara dengan Kasubdit IV Ditreskrimum Polda NTB, AKBP Ni Made Pujewati, SIK., MM, Polda NT, Tanggal 15 Oktober 2018. 
maka kemandirian Polri merupakan salah satu pilar untuk mewujudkan masyarakat madani. Aspek struktural menyangkut institusi, organisasi, susunan dan kedudukan. Perubahan instrumental melibatkan perubahan filosofi, doktrin, kewenangan, kompetensi, kemampuan fungsi dan iptek. Sementara perubahan kultural memusatkan pada manajemen sumber daya, manajemen operasional dan sistem pengawasan masyarakat, yang pada gilirannya akan berakibat pada perubahan tata laku, etika dan budaya pelayanan kepolisian.

Secara universal, peran polisi dalam masyarakat dirumuskan sebagai penegak hukum (law enforcement officers), pemelihara ketertiban (order maintenance). Peran tersebut di dalamnya mengandung pula pengertian polisi sebagai pembasmi kejahatan (crime fighters). Namun di dalam negara yang sistem politiknya otoriter, makna peran polisi sebagai alat penegak hukum direduksi menjadi alat kekuasaan. Sebagai akibatnya, keberadaan polisi bukannya dekat dan melindungi masyarakat, melainkan sebaliknya berada jauh dari rakyat, dan justru berhadapan dengan rakyatnya. Sementara di negara demokratis, polisi harus transparan dan bukan membela kekuasaan. Oleh karenanya pengawasan terhadap lembaga yang memiliki alat kekerasan ini mesti dilakukan oleh rakyat, lewat badan independen yang menjamin transparansi dan akuntabilitas.

\section{b. Sarana Atau Fasilitas Pendukung}

Keterampilan serta kerapihan para pelaku human trafficking dalam melakukan kejahatannya, membuat aparat kepolisian mengalami kesulitan dalam mengungkap kasus yang berkaitan dengan human trafficking. Keterbatasan jumlah personil serta terbatasnya dana, menjadi alasan klasik aparat kepolisian dalam mengungkap kasus-kasus human trafficking. Keterbatasan tersebut bertambah lagi bila dikaitkan dengan kemampuan personil penyidik dalam mengungkap kasus-kasus yang dilaporkan oleh masyarakat. Hal demikian juga disampaikan oleh Kasubdit IV Ditreskrimum Polda NTB, AKBP Ni Made Pujewati, SIK., MM, bahwa: ${ }^{9}$

"Menghadapi perdagangan orang memang memiliki kesulitan tersendiri, $\mathrm{ka}$ rena modus operandi pelaku sulit diketahui, terutama modus untuk bekerja, polisi juga kesulotan kalau tidak ada kerjasama masyarakat, minimal ada laporan terkait agen-agen pencari kerja dari masyarakat, kami sulit bertindak kalau nanti masyarakat enggan menginformasikan."

Berkaitan dengan hal tersebut disampaikan oleh Kasubdit IV Ditreskrimum Polda NTB, AKBP Ni Made Pujewati, SIK., MM, yang menyatakan bahwa:

"Dalam menghadapi berbagai tantangan, sebenarnya diperlukan peran masyarakat luas, bukan saja tugas polisi, dengan anggaran yang besar memungkinkan kerjasama dengan berbagai pihak yang di inisisasi oleh Polisi, anggaran penanganan cukup besar untuk penyidikan kasus, tapi untuk menagkal dan menangani semua membutuhkan semua perangkat". ${ }^{10}$

Berdasarkan hasil uraian wawancara minimnya anggaran penanganan kasus, dalam wawancara yang dilakukan menyimpulkan bahwa, minimnya anggaran berpengaruh terhadap pengawasan yang dilakukan. Pengawasan yang dilakukan masih jauh dari optimal mengingat anggaran bagi personil dan kebutuhan operasionalisasi transportasi dan alat pendukung lainnya. ${ }^{11}$

\section{c. Masyarakat}

Penegak hukum berasal dari masyarakat dan bertujuan untuk mencapai kedamaian di

${ }^{9}$ Hasil wawancara dengan Kasubdit IV Ditreskrimum Polda NTB, AKBP Ni Made Pujewati, SIK., MM, Polda NT, Tanggal 15 Oktober 2018.

${ }^{10}$ Hasil wawancara dengan Kasubdit IV Ditreskrimum Polda NTB, AKBP Ni Made Pujewati, SIK., MM, Polda NT, Tanggal 15 Oktober 2018.

${ }^{11}$ Hasil wawancara dengan Kasubdit IV Ditreskrimum Polda NTB, AKBP Ni Made Pujewati, SIK., MM, Polda NT, Tanggal 15 Oktober 2018. 
dalam masyarakat. Setiap warga masyarakat atau kelompok sedikit banyaknya mempunyai kesadaran hukum, persoalan yang timbul adalah taraf kepatuhan hukum, yaitu kepatuhan hukum yang tinggi, sedang, atau kurang. Adanya derajat kepatuhan hukum masyarakat terhadap hukum, merupakan salah satu indikator berfungsinya hukum yang bersangkutan.

Faktor masyarakat diungkapkan oleh Kasubdit IV Ditreskrimum Polda NTB, AKBP Ni Made Pujewati, SIK., MM dalam wawancara yaitu: ${ }^{12}$

"Kesadaran masyarakat terhadap upaya pencegahan masih kurang, ini ditunjukan melalui tidak terlibat aktifnya masyarakat dalam kegiatan-kegiatan yang mencoba memberantas tindak pidana orang, kami selalu mensosialisasikan terutama melalui Babinkabtibmas, tapi tetap saja masyrakat tergiur, karena memang alasan dari perekrut hanya bekerja biasa, namanya keadaan ekonomi yang mendorong mereka mau, jadi yang ndak masuk akalpun di iyakan".

Kurangnya pengetahuan dan kesadaran masyarakat cukup berperan dalam pencegahan tidak pidana perdagangan orang, sehingga peranan Polda NTB semakin sulit apabila masyarakat juga tidak ikut ambil bagian dalam mengupayakan pemberantasan karena kurangnya pemahaman.

Mengahadapi beberapa faktor tersebut upaya pembangunan sumber daya manusia merupakan instrumen utama dalam pengembangan penyelenggraan pariwisata halal di NTB. Berdasarkan Indeks Pembangunan Manusia (IPM) yang dikeluarkan oleh Badan Pusat Statistik pada tahun 2016, NTB berada pada status sedang denganIPM65,81. ${ }^{13}$ Pendekatanpembangunan

${ }^{12}$ Hasil wawancara dengan Kasubdit IV Ditreskrimum Polda NTB, AKBP Ni Made Pujewati, SIK., MM, Polda NT, Tanggal 15 Oktober 2018.

13 Indeks Pembangunan Manusia 2016, Bada Pusat Statistik, Lampiran 3, hlm, 110, publikasi pada www.bps. go.id, link: https://www.bps.go.id/index.php/publikasi/index?Publikasi page $=2$ manusia menggabungkan aspek produksi dan distribusi komoditas, serta peningkatan dan pemanfaatan kemampuan manusia. Pembangunan manusia melihat secara bersamaan semua isu dalam masyarakatpertumbuhan ekonomi, perdagangan, ketenagakerjaan, kebebasan politik ataupun nilai-nilai kultural-dari sudut pandang manusia. Dengan demikian, pembangunan manusia tidak hanya memperhatikan sektor sosial, tetapi merupakan pendekatan yang komprehensif dari semua sektor.

Soerjono Soekanto menyatakan bahwa penegak hukum berasal dari masyarakat dan bertujuan untuk mencapai kedamaian di dalam masyarakat. Setiap warga masyarakat atau kelompok sedikit banyaknya mempunyai kesadaran hukum, persoalan yang timbul adalah taraf kepatuhan hukum, yaitu kepatuhan hukum yang tinggi, sedang, atau kurang. Adanya derajat kepatuhan hukum masyarakat terhadap hukum, merupakan salah satu indikator berfungsinya hukum yang bersangkutan. ${ }^{14}$

Titik masalah yang menonjol menyangkut faktor masyarakat didalam kaitannya dengan penegakkan hukum terutama pada anggapan dari masyarakat bahwa hukum adalah identik dengan penegak hukum (atau sebaliknya) mengakibatkan harapan-harapan yang tertuju pada peranan aktual penegak hukum menjadi terlampau banyak, sehingga mungkin mengakibatkan terjadinya kebingungan pada diri penegak hukum, oleh karena terjadinya berbagai konflik dalam dirinya. ${ }^{15}$

Secara umum hukum pidana berfungsi mengatur dan menyelenggarakan kehidupan masyarakat agar dapat tercipta dan terpeliharanya ketertiban umum. ${ }^{16}$ Pembinaan bidang hukum harus mampu mengarahkan dan menampung kebutuhankebutuhan hukum sesuai dengan kesadaran hukum rakyat yang berkembang ke arah modernisasi menurut tingkat kemajuan pembangunan di segala bidang sehingga

\footnotetext{
${ }^{14}$ Soerjono Soekanto, Op.Cit. hal. 51

${ }^{15}$ Ibid. hlm 54

${ }^{16}$ Adami Chazawi. (2008). Pelajaran Hukum Pidana. Jakarta: Raja Grafindo Persada, hlm. 15
} 
tercapai ketertiban dan kepastian hukum sebagai prasarana yang harus ditujukan ke arah peningkatan pembinaan kesatuan bangsa, sekaligus berfungsi sebagai sarana menunjang perkembangan modernisasi dan pembangunan yang menyeluruh. Untuk itu, selain fungsi utama hukum pidana sebagai alat untuk penindakan juga sebagai cara untuk membentuk pola kesadaran hukum masyarakat.

Selain itu, upaya penegakan hukum tidak bisa dilimpahkan sepenuhnya pada fungsi hukum pidana yang identitik sebagai alat menindak pelaku kejahatan dalam fungsinya yang represif. Upaya menjaga ketertiban dan keamanan merupakan upaya dari keseluruhan komponen, baik lembaga pemerintahan maupun organisasi kemasyarakatan. Peningkatan ekonomi melalui pembukaan lapangan kerja baru oleh Pemerintah ataupun kebijakan-kebijakan yang mengarahkan pada pemerataan ekonomi masyarakat merupakan unsur terpenting dalam menekan tindak pidana perdagangan orang.

\section{d. Kebudayaan}

Kebudayaan menurut Soerjono Soekanto, mempunyai fungsi yang sangat besar bagi manusia dan masyarakat, yaitu mengatur agar manusiadapatmengertibagaimanaseharusnya bertindak, berbuat, dan menentukan sikapnya kalau mereka berhubungan dengan orang lain. Dengan demikian, kebudayaan adalah suatu garis pokok tentang perikelakuan yang menetapkan peraturan mengenai apa yang harus dilakukan, dan apa yang dilarang. ${ }^{17}$

Kebudayaan dibangun berdasar pada sejarah yang panjang, maka sedikit banyak sangat mempenagruhi pergaulan sosial masyarakat. Tingkat kepatuhan masyarakat terhadap hukum juga sangat dipengaruhi oleh budaya. Oleh karena itu, pendekatan penanggulangan kejahatan harus memperhatikan budaya setempat, Kasubdit IV Ditreskrimum Polda NTB, AKBP Ni Made Pujewati, SIK., MM mengatakan bahwa: ${ }^{18}$

\footnotetext{
17 Soerjono Soekanto, Op.Cit.hlm. 64

${ }^{18}$ Hasil wawancara dengan Kasubdit IV Ditreskrimum Polda NTB, AKBP Ni Made Pujewati, SIK., MM, Polda NT,
}

"Budaya masyarakat NTB sangat kuat, perempuan dianggap berada dibawah laki-laki, mereka kurang pendidikan karena budaya yang mendahulukan laki-laki, jadinya minimnya pendidikan mereka ini yang menjadi kesulitan tersendiri untuk kita penegak hukum juga, kami menyampaikan cara-cara hadapi perdagangan orang, jadi kalau minim pendidikan, kami jadi kesulitan berkomunikasi”.

Berdasarkan hal tersebut di atas, bahwa tingkat pendidikan yang rendah, juga menjadi salah satu faktor yang dapat menjerumuskan anak perempuan ke dalam praktik perdagongan manusia yang juga menjadi satu kesatuan dengan faktor kebudayaan. Dengan demikian, sistem pengetahuan lokal sangat dipengaruhi oleh budaya, dalam budaya masyarakat yang patriarki, masih terdapat diskriminasi gender. Perempuan dan anak perempuan seolah hanya jadi pelengkap seksualitas don dianggap rendah. Budaya yang sudah mengakar Sejak dulu itu sulit sekali diubah. Kondisi ini diperparah oleh kemiskinan, pengangguran, kawin usia dini, serta budaya masyarakat yang hanya mencari pekerjaan bukan menciptakan lapangan kerja.

\section{KESIMPULAN}

Bentuk-bentuk tindak pidana perdagangan orang berdasarkan Undang-undang Nomor 21 Tahun 2007 yaitu: Pertama, Proses perekrutan eksploitasi seksual (prostitusi) dilakukan melalui pemberian pengaruh terhadap korban dan kelurga maupun masyarakat dengan menawarkan pekerjaan yang menguntungkan pada tempat tujuan, kemudian membuat keterikatan agar korban melakukan caracara yang diluar kesepakatan dan tidak bisa kembali dengan mudah ke tempat asal. Kedua, Perdagangan anak sebagai pekerja dengan memanfaatkan keterbatasan fisik dan psikologis anak untuk memenuhi tenaga kerja kasar. Ketiga, perdagangan anak melalui

Tanggal 15 Oktober 2018. 
adopsi (pengangkatan anak) yaitu dengan memanfaatkan keterbatasan pengetahuan orang tua asli, hanya memenuhi beberapa persyaratan yang belum menjamin kepastian hukum, seperti dengan hanya menggunakan akta notaris tanpa putusan pengadilan. Keempat, Perekrutan melalui pernikahan dan pengantin pesanan yaitu perkawinan digunakan sebagai jalan penipuan untuk mengambil perempuan dan membawa ke wilayah lain yang sangat asing serta perkawinan untuk memasukkan perempuan kedalam rumah tangga untuk mengerjakan pekerjaan-pekerjaan domestik yang sangat eksploitatif bentuknya, juga pengantin pesanan yang merupakan pernikahan paksa dimana pernikahannya diatur orang tua

Kendala-kendala Kepolisian Daerah Nusa Tenggara Barat, dalam penanggulangan tindak pidana perdagangan orange yaitu kendala dalam aspek struktur hukum (penegak hukum), sarana atau fasilitas pendukung, faktor masyarakat dan faktor kebudayaan. Kendala struktur hukum (penegak hukum) yaitu berkaitan dengan kemampuan penegak hukum dalam memahami substansi hukum, pembacaan modus operandi, kerjasama lintas sektor dan mentalitas penegak hukum. Kendala sarana atau fasilitas pendukung yaitu berkaitan dengan penunjang operasionalisasi yang meliputi anggaran pencegahan, ketersediaan sistem dan instrumen kerjasama lintas sekto. Faktor masyarakat yaitu kesadaran hukum masyarakat dalam bekerjasama untuk menginformasikan lebih awal agen-agen pencari kerja dan kesadaran masyarakat untuk mengetahui bentuk-bentuk perdagangan orang. Faktor kebudayaan yaitu sistem pengetahuan lokal sangat dipengaruhi oleh budaya, dalam budaya masyarakat yang patriarki, masih terdapat diskriminasi gender.

\section{DAFTAR PUSTAKA}

\section{Buku}

Abidin Farid Zainal. (2010). Hukum Pidana I. Cet. Ke-3. Jakarta: Sinar Grafika.

Amiruddin dan H. Zaenal Asikin. (2004)
Metode Penelitian Hukum. Jakarta: Rajawali Pers.

Apeldoorn Van. (2001). Pengantar Ilmu Hukum. Cet.Ke-29. Jakarta: Pradnya Paramita.

Badan Reserse Kriminal Polri. (2004). Pointer tentang Perdagangan Orang. Jakarta: Mabes Polri.

Darwin Muhadjir. (2003). Pekerja Migran dan Seksualitas. Yogyakarta : Center for Population and Policy Studies Gadjah Mada University.

Deputi Seswapres Bidaag Politik, Lokakarya. (2007). Makalah "Pemberantasan Tindak Pidana Perdagangan Orang dan Implementasi UU No 21 tahun 2007, Medan, 10 Mei 2007

International Labour Organization, Bunga - Bunga di Atas Padas: Fenomena Pekerja Rumah Tangga Anak di Indonesia, Jakarta : ILO - APEC, 2004

Lamintang. (2014). Dasar-Dasar Hukum Pidana. Jakarta: Sinar Grafika.

Peter Mahmud Marzuki. (2015). Pengantar Ilmu Hukum. Cet.Ke-7. Jakarta: Prenadamedia Group.

Nawawi Arief Barda. (2010). Bunga Rampai Kebijakan Hukum Pidana (Perkembangan Penyusunan Konsep KUHP Baru). Cet.Ke-2. Jakarta: Kencana Prenada.

Sadhi Astuti Made. (2003). Hukum PidanA Anak dan Perlindungan Anak. Malang: UNM Press.

Soerjono Soekanto. (2004). Faktor-Faktor Yang Mempengaruhi Penegeakan Hukum Cet.Ke-5. Jakarta: Raja Grafindo Persada.

The United National Convention Against Transnational Organized Crime. Tahun 2002

Utrecht. (tt). Hukum Pidana I (Rangkaian 
Sari Kuliah). Jakarta: Penerbit Universitas.

\section{Peraturan Perundang-Undangan}

Undang-Undang Dasar Negara Republik Indonesia Tahun 1945

Kitab Undang-Undang Hukum Pidana

Undang-Undang Nomor 39 Tahun 1999 tentang Hak Asasi Manusia

Undang-Undang Nomor 23 Tahun 2002 tentang Perlindungan Anak

Undang-Undang Nomor 21 Tahun 2007 tentang Tindak Pidana Perdagangan Orang

Undang-Undang Nomor 35 Tahun 2014 tentang Perubahan Atas UndangUndang Nomor 23 Tahun 2002 tentang Perlindungan Anak

Keputusan Presiden Nomor 59 Tahun 2002 tentang Rencana Aksi Nasional ( RAN ) Penghapusan Bentuk Bentuk Pekerjaan Terburuk untuk Anak

Keputusan Presiden. Nomor 88 Tahun 2002 tentang Rencana Aksi Pengahapusan Perdagangan Perempuan dan Anak

\section{Internet}

Codeto Penale Internationale, What are crimes against humanity?, http:// www.icc-cpi.int/en menus/ icc/about $\% 20$ the $\% 20$ court/ frequently\%20asked\%20questions/ Pages/12.aspx

Gugus Tugas Nasional Pencegahan dan Penanganan Tindak Pidana Perdagangan Orang Pemerintah, website resmi, Indonesia http:// www.gugustugastrafficking.org/ index.php/index.php?option $=$ com content\&view $=$ category\&layout $=$ bl og\&id=113\&Itemid $=53$

Indeks Pembangunan Manusia 2016, Bada Pusat Statistik , Lampiran 3, hlm, 110, publikasi pada www.bps.go.id, link: $\quad$ https://www.bps.go.id/index. $\mathrm{php/publikasi/index?Publikasi}$ page $=2$

Sindonews, $\quad$ http://daerah.sindonews. $\mathrm{com} / \mathrm{read} / 1012581 / 174 / \mathrm{ibu}-$ angkat-angeline-lupa-daftarkanakta-pengangkatan-anak-kepengadilan-1434298349, diakses pada tanggal 24 Oktober 2015, pukul 21.40 Witeng

Gugus Tugas Nasional Pencegahan dan Penanganan Tindak Pidana Perdagangan Orang Pemerintah Indonesia, $\quad$ http://www. gugustugastrafficking.org/index. php/index.php?option $=$ com content \&view $=$ category\&layout $=$ blog\&id $=$ $\underline{113 \& \text { Itemid }=53}$ 